\title{
ANALISIS MANFAAT MUDHARABAH MUQAYYADAH PRODUK PEMBIAYAAN LINKAGE PADA BANK BRI SYARIAH CABANG PURWOKERTO
}

\author{
Murdiyah ${ }^{1}$, Encep Saepudin ${ }^{2}$ \\ 1Universitas Muhammadiyah Purwokerto, Email : dmurdiyah@gmail.com \\ 1Universitas Muhammadiyah Purwokerto, Email : encep1972@gmail.com
}

\begin{abstract}
ABSTRAK
Penelitian ini bertujuan untuk Untuk mengetahui penerapan akad mudharabah pada produk pembiayaan linkage di Bank BRI Syariah Purwokerto dan mengetahui manfaat pemilihan akad mudharabah muqayyadah pada produk linkage di Bank BRI Syariah cabang Purwokerto. Jenis penelitian ini adalah penelitian lapangan (field research) yang berjenis kualitatif, penelitian dilakukan di Bank BRI Syariah cabang Purwokerto. Metode pengumpulan data dalam penelitian dilakukan dengan cara wawancara, observasi dan dokumentasi. Hasil penelitian ini menunjukan bahwa proses pelaksanaan pembiayaan linkage di Bank BRI Syariah cabang Purwokerto yaitu Kopkar (Koperasi Karyawan) atau KPRI mengajukan permohonan pembiayaan, setelah itu Bank melakukan BI Checking terhadap koperasi, kemudian wawancara dan pemenuhan dokumen persyaratan, bank melakukan analisa layak atau tidaknya koperasi diberikan pembiayaan, setelah itu On the Spot (OTS) dan transaksi jaminan, kemudian koperasi menandatangani surat pesetujuan pembiayaan setelah itu dilakukan akad pembiayaan dan kemudian Bank BRI Syariah melakukan pencairan pembiayaan. Bank BRI Syariah menyalurkan pembiayaan linkage kepada koperasi dengan menggunakan mudharabah muqayyadah karena memiliki banyak manfaat baik dari beberapa pihak yaitu : Bank BRI Syariah (shahibul maal), koperasi (mudharib) dan anggota koperasi.
\end{abstract}

Kata-kata kunci : Mudharabah, Linkage, Bank Syariah

\begin{abstract}
This study aims to determine the application of mudharabah agreement on linkage financing products at Bank BRI Syariah Purwokerto and find out the benefits of selecting mudharabah muqayyadah contract in linkage products at Bank BRI Syariah Purwokerto branch. This type of research is a qualitative research field (field research), the study was conducted at the Bank BRI Syariah Purwokerto branch. The method of data collection in research is done by interview, observation and documentation. The results of this study indicate that the process of implementing linkage financing at the Bank BRI Syariah Purwokerto branch, namely Kopkar (Employee Cooperative) or KPRI submits a request for financing, after that the Bank conducts BI Checking on cooperatives, then interviews and fulfills requirements documents, the bank conducts a feasible or not cooperative analysis financing is given, then On the Spot (OTS) and collateral transaction, then the cooperative
\end{abstract}


signs a letter of financing approval after the financing agreement is made and then BRI Syariah Bank disburses the financing. BRI Bank Syariah distributes linkage financing to cooperatives using mudharabah muqayyadah because it has many benefits from several parties, namely: BRI Syariah Bank (shahibul maal), cooperative (mudharib) and cooperative members.

Keywords: Mudharabah, Linkage, Islamic Bank

\section{PENDAHULUAN}

Bank adalah badan usaha yang menghimpun dana dari masyarakat dalam bentuk simpanan dan menyalurkannya kepada masyarakat dalam bentuk kredit dan/atau bentuk lainnya dalam rangka meningkatkan taraf hidup rakyat banyak (Ismail, 2011: 30). Bank syariah merupakan bank yang menjalankan kegiatan usahanya menggunakan prinsip-prinsip syariah (Andri, Soemitra, 2009 : 61). Bank syariah banyak diminati oleh masyarakat karena sistemnya sesuai dengan syariat yang membuat nasabah tidak ragu akan sistem yang dijalankan dan tidak melanggar ajaran Islam. Bank syariah menghasilkan sejumlah produk yang akan memberikan kemudahan kepada nasabah untuk memilih sesuai dengan kebutuhan yang diinginkan oleh nasabah. Bank syariah memiliki ciri khas yaitu tidak menerima atau membebankan bunga kepada nasabah, akan tetapi menerima atau membebankan bagi hasil serta imbalan lain sesuai dengan akad-akad yang diperjanjikan. Konsep dasar bank syariah didasarkan pada Al-Qur'an dan Hadits (Ismail, $2011: 29$ ).

Pelayanan lembaga keuangan syariah terus bertambah sebagai upaya untuk memenuhi kebutuhan pasar. Dari produk penghimpun dana (funding), pembiayaan (landing), dan produk tambahan berupa jasa (service). Salah satu pembiayaaan di perbankan syariah adalah pembiayaan mudharabah yang menegaskan kerja sama dalam panduan kontribusi $100 \%$ modal kas dari shahibul maal dan keahlian dari mudharib (Lestrari, 2015 : 127). Salah satu produk dari pembiayaan mudharabah yaitu linkage programe. Linkage Programe adalah program kerjasama antara bank umum termasuk bank umum peserta KUR dengan koperasi dalam rangka meningkatkan akses pembiayaan Usaha Mikro dan Kecil (UMK) (Peraturan Menteri No. 03/Per/M.KUKM.III/2009). Linkage program merupakan salah satu upaya membuka akses modal bagi usaha mikro, kecil, menengah (UMKM) yang potensial, tetapi terkendala dalam modal karena termasuk dalam kategori 
unbankable. Linkage program menjadi salah satu solusi bagi sektor UMKM untuk mendapatkan akses pembiayaan sebagai tambahan modal untuk mengembangkan usahanya. Lembaga keuangan mikro seperti koperasi, BMT, dan BPRS dirasa lebih efektif dalam memberi kontribusi dalam mengembangkan UMKM karena dinilai lebih dekat dengan masyarakat. Pemerintah melalui Menteri Negara Koperasi dan Usaha Kecil dan Menengah mendukung linkage program ini dengan mengeluarkan regulasi melalui Peraturan Menteri Negara Koperasi dan UKM No. 03/Per/M.KUKM.III/2009 tentang Pedoman Umum linkage programe Antara Bank Umum dengan Koperasi (http://Financial.id/Newsreader/1582, 26/10/2016).Upaya implementasi peran bank syariah dalam memajukan sektor riil, Bank Indonesia (BI) mendorong bank syariah lebih produktif dalam memberikan kontribusinya khususnya pada sektor UMKM. Bank Indonesia (BI) mendorong bank-bank syariah melakukan kerja sama atau linkage program dengan lembaga keuangan mikro syariah seperti Baitul Maal wa Tamwil (BMT) dan Koperasi Jasa Keuangan Syariah (KJKS). Kepentingan membangun kerja sama antara bank syariah dengan lembaga keuangan mikro syariah bersifat mutual benefit atau timbal balik yang bertujuan mengembangkan Usaha Mikro, Kecil dan Menengah (http://www. republika.co.id, 26/10/2016).

Bank BRI Syariah Cabang Purwokerto sebagai lembaga syariah mempunyai produk pembiayaan yang menggunakan pola linkage. Program ini menggunakan praktik mudharabah dalam pembiayaannya, sedangkan mitra linkage yang diberi dana adalah koperasi. Koperasi disini menjadi perantara penyaluran dana yang diperoleh dari bank BRI Syariah kepada koperasi dibawah naungan institusi atau koperasi karyawan (Kopkar). Koperasi menyalurkan kembali dananya kepada anggota dan nonanggota berdasarkan pembagian risiko bisnis. Anggota koperasi yang dimaksud dalam linkage program ini adalah anggota tetap atau karyawan yang sesuai dengan kriteria yang telah ditentukan oleh koperasi itu sendiri.

Pembiayaan mudharabah masih memiliki keterbatasan dalam hal peraturan perundang-undangan yang mendukung sehingga perbankan syariah terpaksa berusaha menyesuaikan produk-produknya dengan hukum perbankan yang berlaku umum (konvensional). Akibatnya, ciri-ciri syariah Islam yang melekat padanya tersamar, sehingga perbankan syariah 
tampil seperti perbankan konvensional, berikut konsekuensi-konsekuensi lain bagi sistem operasionalnya. Itulah salah satu sebab lambatnya pemahaman masyarakat terhadap sistem perbankan syariah, dan bahkan menyebabkan timbulnya persepsi-persepsi yang salah dikalangan masyarakat, termasuk kalangan perbankan, cendekiawan dan kalangan ulama Islam itu sendiri (Muhammad, 2005: 47).

\section{METODE PENELITIAN}

Penelitian ini termasuk jenis penelitian kualitatif. Penelitian kualitatif adalah penelitian yang bermaksud untuk memahami fenomena yang dialami oleh subjek penelitian. Apabila seseorang melakukan penelitian dengan sasaran penelitian yang terbatas, tetapi dengan keterbatasan sasaran penelitian yang ada itu digali sebanyak mungkin data mengenai sasaran penelitian (Masyhuri\&Zainuddin, 2009: 13-14). Dalam penelitian ini penulis memilih tempat pelaksanaan penelitian di daerah Purwokerto pada Bank BRI Syariah cabang Purwokerto. Teknik pengumpulan data penelitian ini adalah wawancara, observasi, dan dokumentasi. Data yang telah dikumpulkan baik dari penelitian, kepustakaan maupun penelitian lapangan, selanjutnya dianalisa berdasarkan teori dari penelitian sebelumnya yang menghasilkan penemuan-penemuan yang tidak dapat dicapai (diperoleh) dengan menggunakan prosedur-prosedur statistik atau cara-cara lain dari kuantifikasi (pengukuran).

\section{HASIL DAN PEMBAHASAN}

Berawal dari akuisisi PT. Bank Rakyat Indonesia (Persero), Tbk. Terhadap Bank Jasa Arta pada 19 Desember 2007 dan setelah mendapatkan izin dari Bank Indonesia pada 16 Oktober 2008 melalui suratnya 10/67/KEP.GBI/DpG/2008, maka pada tanggal 17 November 2008, PT. Bank BRI Syariah secara resmi beroperasi. Saat ini PT. Bank BRI Syariah menjadi bank syariah ketiga terbesar berdasarkan aset. PT. Bank BRI Syariah tumbuh dengan pesat baik dari sisi aset, jumlah pembiayaan dan perolehan dana pihak ketiga. Dengan berfokus pada segmen menengah bawah, PT. Bank BRI Syariah menargetkan menjadi bank ritel modern terkemuka dengan berbagai ragam produk dan layanan perbankan. Pembiayaan linkage BRI Syariah adalah pembiayaan dimana BRI Syariah sebagai pemilik dana menyalurkan pembiayaan dengan pola executing kepada lembaga 
keuangan syariah (BMT, Koperasi, BPRS, dll). Dalam pembiayaan linkage di BRI Syariah menggunakan akad mudharabah. Maksimal jangka waktu dalam pembiayaan linkage 3 (tiga) tahun.

\section{Pembiayaan Koperasi}

Pembiayaan yang diberikan melalui Koperasi Karyawan atau Koperasi Pegawai RI dengan mekanisme executing, yang ditujukan kepada karyawan suatu perusahaan atau Pegawai Negeri Sipil (PNS) suatu instansi yang memiliki pendapatan tetap bulanan berupa gaji dan menjadi anggota koperasi. Mekanisme executing adalah kondisi dimana Kopkar atau KPRI bertindak selaku badan hukum yang melakukan perjanjian pembiayaan dengan Bank BRI Syariah sehingga Kopkar atau KPRI bertanggung jawab penuh terhadap pengembalian pembiayaan tersebut kepada Bank BRI Syariah, namun Kopkar atau KPRI tetap berkewajiban untuk menyalurkan pembiayaan yang diterimanya kepada karyawan atau PNS yang menjadi anggotanya dengan skema sebagai berikut ini :

4. Pembayaran pokok dan bagi hasil

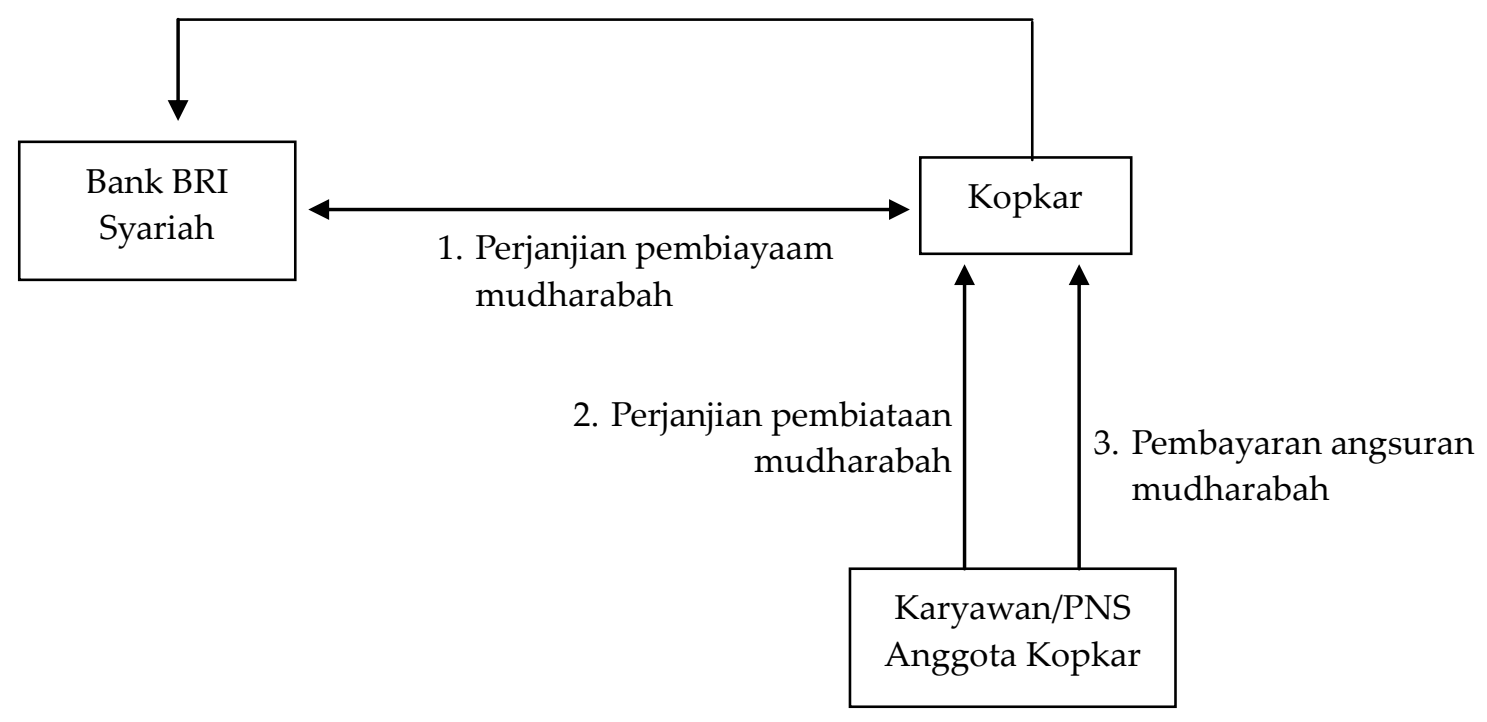

Gambar 1 : Skema transaksi Pembiayaan Linkage

Sumber: Juklak Bank BRI Syariah

Keterangan : 
1. Bank BRI Syariah memberikan fasilitas pembiayaan mudharabah kepada Kopkar (koperasi karyawan) atau KPRI.

2. Kopkar (koperasi karyawan) atau KPRI menyalurkan pembiayaan kepada para anggotanya menggunakan perjanjian pembiayaan murabahah. Dalam hal ini anggota Kopkar (koperasi karyawan) atau KPRI membeli barang secara murabahah kepada Kopkar (koperasi karyawan) atau KPRI.

3. Anggota Kopkar (koperasi karyawan) atau KPRI membayar angsuran kepada Kopkar (koperasi karyawan) atau KPRI.

4. Bank BRI Syariah dan Kopkar (koperasi karyawan) atau KPRI melakukan bagi hasil atas pendapatan marjin angsuran murabahah yang diperoleh Kopkar (koperasi karyawan) atau KPRI dari para anggotanya.

Skema transaksi linkage berdasarkan syariah :

1. Dalam pembiayaan menggunakan skema mudharabah

2. Rukun-rukun (unsur-unsur pokok) yang harus ada dalam transaksi

a. Shahibul maal (pemilik dana) : Bank BRI Syariah

b. Mudharib (pengelola dana) : Kopkar (koperasi karyawan)

c. Obyek mudharabah: pendapatan marjin murabahah yang diperoleh kopkar (koperasi karyawan) dari para anggotanya.

Pelaksanaan atau praktik pembiayaan mudharabah pada produk linkage Bank BRI Syariah cabang Purwokerto linkage program dengan BRI Syariah maka harus mengikuti standar oprasianal sebaga berikut :

1. Kopkar (Koperasi Karyawan) atau KPRI mengajukan permohonan pembiayaan kepada Bank BRI Syariah (dianjurkan untuk memilih cabang terdekat).

2. BI Checking. Merupakan alat bantu paling utama bagi bank dalam menganalsis kredit yang akan dilakukan oleh koperasi. BI Checking ini akan mengetahui hubungan kredit apa saja yang dilakukan koperasi dalam beberapa tahun ini, serta mengetahui informasi permasalahan yang pernah dilakukan koperasi tersebut kepada lembaga keuangan lainnya dan hal ini dilakukan oleh bank BRI Syariah untuk mencegah terjadinya risiko yang terjadi.

3. Wawancara dan pemenuhan dokumen persyaratan : 
a. Syarat-syarat yang harus dipenuhi oleh anggota koperasi dalam pembiayaan linkage pada koperasi :

1) KTP suami istri.

2) Fotocopy Kartu Keluarga, Surat nikah, dan NPWP.

3) Fotocopy Surat Keputusan Pengangkatan karyawan tetap.

4) Slip gaji 1 bulan.

5) Persetujuan HRD.

6) SKPG.

b. Adapun persyaratan yang harus dipenuhi oleh koperasi dalam melakukan pembiayaan linkage, yaitu :

1) Akta pendirian Koperasi

2) Anggaran perubahan dasar

3) Daftar pengurus Koperasi

4) Laporan keuangan Koperasi

5) KTP (seluruh anggota Koperasi)

6) NPWP

7) SIUP (Surat Ijin Usaha Perdagangan)

c. Kriteria Kopkar yang akan melakukan pembiayaan

1) Koperasi berasal dari Perusahaan BUMN atau BUMD, Perusahaan Multinasional, dan Lembaga Pemerintahan.

2) Koperasi memenuhi persyaratan keabsahan badan hukum dari Dinas atau kementrian koperasi wilayah kerjanya maupun persyaratan perijinan usaha (NPWP, TDP, SIUP, dan Keterangan Domisili).

3) Telah beroperasi minimal 3 tahun.

4) Membukukan laba atau keuntungan bersih dalam 2 tahun terakhir.

5) Wajib memberikan laporan keuangan yang diaudit oleh Kantor Akuntan Publik (KAP) bagi Koperasi yang memiliki total asset diatas Rp 20 miliar.

6) Melaksanakan RAT minimal 3 tahun berturut-turut ditandai dengan buku Laporan RAT.

7) Tidak termasuk dalam Daftar Hitam Bank Indonesia dan tidak memiliki kredit macet di perbankan.

d. Kriteria anggota Kopkar (koperasi karyawan) 
1) WNI

2) Karyawan tetap

3) Telah menjadi anggota minimal 1 tahun

4) Usia maksimal jatuh tempo pembiayaan adalah 54 tahun atau 1 tahun sebelum usia pensiun

5) Jumlah kewajiban angsuran pembiayaan (pokok dan marjin) perbulan tidak melebihi $40 \%$ dari take home pay.

4. Analisa layak atau tidaknya diberikan pembiayaan linkage di Bank BRI Syariah.

5. On the Spot (OTS) dan transaksi jaminan. Bank menilai kelayakan langsung perusahaan yang mengajukan pembiayaan dengan mendatangi langsung survey langsung ke perusahaan. Analisa layak atau tidaknya diberikan pembiayaan linkage program di Bank BRI Syariah.

6. Penandatanganan surat pesetujuan pembiayaan di Bank BRI Syariah. Pihak yang melakukan pembiayaan yaitu Kopkar atau KPRI melakukan penandatangan berkas-berkas di Bank BRI Syariah dan berkas-berkas akan diserahkan kepada pimpinan cabang untuk meminta persetujuan pemimpin layak tidaknya Kopkar atau KPRI untuk diberikan pembiayaan.

7. Akad Pembiayaan. Akad dalam melakukan pembiayaan linkage program yaitu akad mudharabah dan kesepakatan akad disepakati kedua belah pihak. Artinya bahwa pembiayaan telah di setujui oleh Bank BRI Syariah bagi yang melakukan pembiayaan. Dalam akad pembiayaan terdapat persetujuan pembiayaan juga kesepakatan antara bank dengan koperasi mengenai pembagian bagi hasil dan juga nisbah yang harus dipatuhi keduanya.

8. Pencairan pembiayaan. Artinya bahwa pembiayaan yang diajukan oleh Kopkar (Koperasi Karyawan) atau KPRI disetujui oleh Bank BRI Syariah. Ketentuan dan syarat-syarat pencairan :

a. Penarikan dilakukan per batch dikelompokan berdasarkan jangka waktu pembiayaan dengan jumlah per batch minimum telah ditentukan sesuai dengan kesanggupan masing-masing Unit Bisnis.

b. Kopkar (Koperasi Karyawan) atau KPRI menyerahkan : 
1) Surat permohonan pencairan dana

2) Daftar Definitif dalam bentuk soft copy maupun hard copy yang telah ditandatangani pejabat Kopkar (Koperasi Karyawan) atau KPRI yang berwenang.

3) Daftar instruksi transfer dana sesuai nama-nama end-user yang tercantum dalam daftar definitif dan ditandatangani pejabat Kopkar (Koperasi Karyawan) atau KPRI yang berwenang.

4) TTUN (Tanda Terima Uang Nasabah) sejumlah nilai pencairan yang ditandatangani pejabat Kopkar (Koperasi Karyawan) atau KPRI yang berwenang.

5) Proyeksi pembiayaan sejumlah nilai pencairan.

6) Dokumen-dokumen yang harus di penuhi, yaitu :

a) Fotocopy aplikasi permohonan pembiayaan dari anggota kepada Kopkar (Koperasi Karyawan) atau KPRI.

b) Fotocopy perjanjian pembiayaan murabahah antara anggota dengan Kopkar (Koperasi Karyawan) atau KPRI.

c) Surat kuasa pemotongan gaji dari masing-masing anggota kepada bendahara gaji (payroll) perusahaan atau instansi.

d) Fotocopy slip gaji anggota bulan terakhir.

e) Fotocopy KTP anggota, suami atau isteri dan Kartu Keluarga (KK) atau Akte Nikah.

f) Surat persetujuan suami atau isteri anggota Kopkar (Koperasi Karyawan) atau KPRI.

g) Khusus untuk PNS, menyerahkan :

(1) Asli SK pengangkatan awal dan SK terakhir.

(2) Asli kartu Pegawai.

(3) Asli kartu Taspen.

Mekanisme bagi hasil di Bank BRI Syariah Cabang Purwokerto adalah berbagi hasil dalam bank syariah menggunakan istilah nisbah bagi hasil, yaitu proporsi bagi hasil antara nasabah dan bank syariah. Nisbah bagi hasil ditentukan dengan cara membagi expected yield Bank BRI Syariah dengan rate marjin Kopkar (Koperasi Karyawan) atau KPRI kepada para anggotanya.

1. Contoh perhitungan nisbah Bagi Hasil sebagai berikut : 
Expected Yield pembiayaan Bank $\quad=15 \%$

Rate marjin koperasi kepada anggota $=18 \%$

Nisbah bagi hasil Bank : Koperasi $\quad=(15 \%: 18 \%)$

$=83,33 \%: 16,67 \%$

2. Penentuan Expected Yield Bank BRI Syariah. Expected Yield Bank BRI Syariah ditentukan secara bertingkat (tier method), dan terbagi menjadi tiga tingkatan berdasarkan jangka waktu, yaitu :

a. Expected Yield untuk jangka waktu pembiayaan 1 tahun

b. Expected Yield untuk jangka waktu pembiayaan 2 tahun

c. Expected Yield untuk jangka waktu pembiayaan 3 tahun

3. Rate marjin Kopkar (Koperasi Karyawan) atau KPRI. Kopkar (Koperasi Karyawan) atau KPRI memiliki kewenangan penuh untuk menentukan besarnya rate marjin yang akan dikenakan kepada para anggotanya. Tetapi, Kopkar (Koperasi Karyawan) atau KPRI wajib memberitahukan besarnya marjin yang didapatkan kepada Bank BRI Syariah.

Linkage di Bank BRI Syariah Purwokerto menggunakan akad mudharabah. Mudharabah yang digunakan yaitu mudharabah muqayyadah, produk dari pembiayaan mudharabah muqayyadah pada Bank BRI Syariah Purwokerto yaitu linkage koperasi. Jenis investasi dalam pembiayaan mudharabah muqqayadah adalah untuk koperasi, dimana Bank BRI Syariah memberikan dananya kepada koperasi karena koperasi membutuhkan dana dan biasanya koperasi mengajukan pembiayaan untuk membiayai anggotanya dengan menggunakan akad murabahah (jual beli). Murabahah adalah jual beli barang pada harga asal dengan tambahan keuntungan yang disepakati. Dalam murabahah, penjual harus memberi tahu harga pokok yang ia beli dan menentukan suatu tingkat keuntungan sebagai tambahannya. Oleh karena itu, transaksi tersebut wajib dipenuhi hal-hal yang berkaitan dengan rukun-rukun murabahah (Widiastuti, 14/12/2016).

Akad antara bank dan nasabah (mudharib) ini digunakan untuk pembiayaan yang disalurkan untuk koperasi atau BMT, karena dalam koperasi atau BMT terjadi kesepakatan-kesepakatan lagi dengan anggotanya. Sedangkan akad mudharabah antara bank dan nasabah (mudharib) berperan sebagai end user. Skema penyaluran pembiayaan mudharabah muqayyadah atau investasi terikat : 


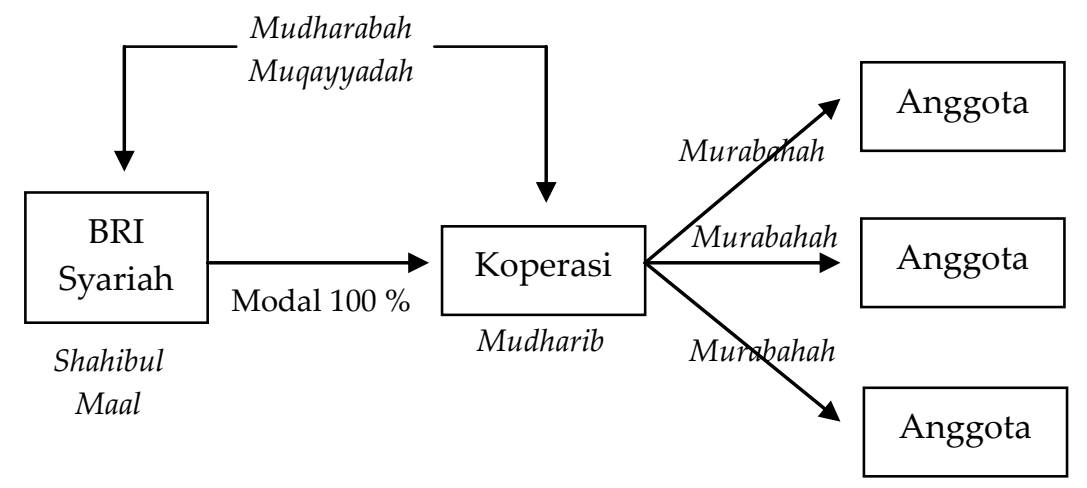

Gambar 2. Penyaluran Pembiayaan Mudharabah Muqqayadah Sumber : Buku panduan karyawan Bank BRI Syariah

Keterangan skema mudharabah muqayyadah

1. Bank BRI Syariah sebagai shahibul maal memberikan modal $100 \%$ kepada koperasi sebagai mudharib.

2. Setelah koperasi mendapatkan dana, koperasi akan menyalurkan dananya kepada anggotanya .

3. Koperasi menyalurkan dana kepada anggota koperasi menggunkan akad murabahah.

Bank BRI Syariah dalam pembiayaan mudharabah produk linkage yang digunakan yaitu jenis mudharabah muqayyadah karena Bank (shahibul maal) memberikan batasan mengenai dimana, bagaimana atau untuk tujuan apa dana tersebut diinvestasikan, proyek yang dijalankan terikat dengan waktu, tempat, dan jenis perusahaan. Koperasi yang diberikan pembiayaan dari Bank BRI Syariah Purwokerto hanya boleh menginvestasikan pembiayaannya kepada anggotanya melalui pembiayaan murabahah (Faiz A.M., 20/1/2017).

Bank BRI Syariah Purwokerto memakai mudharabah muqayyadah karena sejalan dengan visi Bank BRI untuk membangun ekonomi rakyat, dimana bank memberikan pembiayaan kepada koperasi yang membutuhkan dana untuk membiayai anggotanya dan disalurkan oleh koperasi untuk anggotanya melalui akad murabahah, sehingga koperasi dapat memenuhi kebutuhan anggota dan meningkatkan kesejahteraan anggota koperasi (Annisa, 27/12/2016). Alasan bank BRI Syariah menyalurkan pembiayaan linkage dengan menggunakan mudharabah 
muqayyadah karena memiliki banyak manfaat baik dari pihak Bank BRI Syariah (shahibul maal), koperasi (mudharib) dan anggota koperasi.

1. Manfaat pembiayaan mudharabah muqayyadah bagi Bank BRI Syariah selaku shahibul maal, sebagai berikut :

a. Bank akan menikmati peningkatan bagi hasil lebih besar pada saat keuntungan usaha nasabah meningkat.

b. Bank tidak berkewajiban membayar bagi hasil kepada nasabah pendanaan secara tetap, tetapi disesuaikan dengan pendapatan/hasil usaha bank, sehingga bank tidak akan pernah mengalami negative spread.

c. Bank BRI Syariah lebih mudah menyalurkan dananya kepada nasabah karena nasabah harus memenuhi aturan yang dibuat oleh Bank BRI Syariah.

d. Bank akan lebih selektif dan hati-hati mencari usaha yang halal, aman, dan menguntungkan karena keuntungan yang nyata dan benar-benar terjadi itulah yang akan dibagikan sesuai dengan kesepakatan bersama.

e. Prinsip bagi hasil ini berbeda dengan prinsip bunga tetap dengan bank akan menagih penerima pembiayaan (nasabah) satu jumlah bunga yang tetap berapa pun keuntungan yang dihasilkan nasabah dalam pembiayaan linkage menggunakan bagi hasil yang sesuai dengan peraturan yang ada.

2. Manfaat linkage program bagi koperasi selaku penerima pembiyaan dari Bank BRI Syariah Purwokerto, yaitu :

a. Koperasi tidak perlu mengumpulkan dana terlebih dahulu untuk menyalurkan pembiayaan kepada anggotanya, karena koperasi sudah mendapatkan pembiayaan dari bank BRI Syariah Purwokerto untuk disalurkan kepada anggotanya.

b. Koperasi tidak khawatir kalau anggotanya tidak dapat membayar tagihan setiap bulannya karena gaji anggota koperasi dipotong untuk melakukan penyetoran.

c. Koperasi dalam melakukan pembiayaan kepada Bank BRI Syariah Purwokerto lebih aman karena ada asuransi yang menjaminnya.

d. Koperasi dapat mememuhi kebutuhan anggotanya. 
e. Koperasi dapat mensejahterakan para anggotanya dalam memenuhi kebutuhan anggota melalui akad murabahah.

3. Manfaat linkage bagi anggota koperasi, sebagai berikut :

a. Anggota koperasi lebih mudah melakukan pembiayaan kepada koperasi, karena koperasi memiliki modal yang cukup untuk memenuhi kebutuhan anggotanya.

b. Anggota koperasi lebih mudah melakukan penyetoran setiap bulannya karena menggunakan gaji yang telah di potong oleh petugas atau instasi yang berwenang.

c. Anggota koperasi tidak perlu mengumpulkan dana terlebih dahulu untuk koperasi karena sudah mendapatkan pembiayaan dari Bank BRI Syariah Purwokerto.

d. Anggota koperasi dalam melakukan pembiayaan cenderung lebih aman karena ada asuransi yang menjaminnya.

Dengan demikian, jenis mudharabah yang digunakan Bank BRI Syariah Purwokerto yaitu mudharabah muqayyadah memiliki kewenangan kepada pihak mudharib bersifat terbatas, namun pembatasan ini bukan berarti membolehkan keterlibatan pemilik modal dalam mengelola usaha. Koperasi hanya menyalurkan dananya kepada anggotanya menggunakan akad murabahah (jual beli) berupa barang-barang yang dibutuhkan oleh anggota koperasi. Bank BRI Syariah hanya membolehkan koperasi menggunakan dananya untuk membiayai anggotanya menggunakan akad murabahah, karena investasinya terikat oleh bank maka koperasi harus menyalurkan dananya sesuai dengan aturan yang dibuat oleh bank. Melalui pembiayaan murabahah yang disalurkan koperasi kepada anggota koperasi maka koperasi akan mendapatkan keuntungan yang didapatkan dari anggotanya. Dalam hal ini, koperasi atau pengelola dana hanya bertindak sebagai perantara atau agen investasi yang mendapatkan bagian atas jasanya.

Seluruh jenis barang dapat dibiayai oleh koperasi kepada anggotanya, selama barang tersebut halal dan tidak untuk tujuan spekulatif. Contoh barang- barang yang dapat dibiayai oleh koperasi kepada anggota melalui akad murabahah (jual beli), yaitu :

1. Rumah 
2. Bahan-bahan bangunan (untuk pembangunan atau renovasi rumah)

3. Kendaraan (mobil atau motor) baik baru atau sudah lama.

4. Barang-barang elektronik, perabotan rumah tangga.

Koperasi yang mendapatkan pembiayaan linkage dari Bank BRI Syariah Purwokerto yaitu koperasi karyawan (Kopkar) dan Koperasi Pegawai Republik Indonesia (KPRI). Koperasi karyawan (Kopkar) adalah koperasi yang para anggotanya adalah karyawan dari suatu perusahaan baik perusahaan BUMN atau BUMD maupun swasta. Khusus kopkar swasta harus didukung kuat oleh manajemen perusahaan. Koperasi Pegawai Republik Indonesia (KPRI) adalah koperasi yang anggotanya pegawai (PNS) dari suatu instansi atau dinas. Karena pembiayaan yang ditujukan kepada karyawan suatu perusahaan atau Pegawai Negeri Sipil (PNS) suatu instansi yang memiliki pendapatan tetap bulanan berupa gaji. Bank BRI Syariah tidak khawatir kalau anggota koperasi tidak bisa membayar tagihan setiap bulannya karena setiap bulan pada saat pembayaran gaji pertugas perusahaan atau instansi yang berwenang melakukan pemotongan gaji masing-masing karyawan/pegawai koperasi penerima pembiayaan. Kopkar atau KPRI wajib memenuhi kriteria-kriteria yang telah di tentukan oleh Bank BRI Syariah cabang Purwokerto. Koperasi yang pernah melakukan pembiayaan di Bank BRI Syariah cabang Purwokerto, sebagai berikut :

1. Koperasi Gayatri PLN Cilacap

2. Koperasi Braling Tirta PDAM Purbalingga

3. Koperasi Cahaya Tirta Cilacap

4. Koperasi Karyawan Sentra Cilacap

5. Koperasi Pegawai Telkom Purwokerto

6. Koperasi Ebi Purwokerto

\section{PENUTUP}

Pembiayaan Linkage BRI Syariah adalah pembiayaan dimana BRI Syariah sebagai pemilik dana menyalurkan pembiayaan dengan pola executing kepada lembaga keuangan syariah (BMT, Koperasi, BPRS, dll). Mekanisme pola executing adalah kondisi dimana Kopkar atau KPRI bertindak selaku badan hukum yang melakukan perjanjian pembiayaan 
dengan Bank BRI Syariah sehingga Kopkar atau KPRI bertanggung jawab penuh terhadap pengembalian pembiayaan tersebut kepada Bank BRI Syariah, namun Kopkar atau KPRI tetap berkewajiban untuk menyalurkan pembiayaan yang diterimanya kepada karyawan atau PNS yang menjadi anggotanya. Proses pelaksanaan pembiayaan mudharabah pada produk linkage Bank BRI Syariah cabang Purwokerto dari awal sampai akhir yaitu nasabah mengajukan surat permohonan pembiayaan kepada Bank BRI Syariah dengan melampirkan data komplit termasuk syarat-syarat pembiayaan. Kemudian Bank BRI Syariah melakukan BI Cheking terhadap nasabah yang melakukan pembiayaan, setelah itu pihak bank melakukan wawancara kepada nasabah untuk mengetahui lebih lanjut tentang nasabah, setelah itu nasabah memenuhi dokumen-dokumen persyaratan pembiayaan, kemudian bank melakukan analisa layak atau tidaknya nasabah mendapatkan pembiayaan. Setelah dianalisis maka analisis tersebut akan masuk ke komite pembiayaan yang anggotanya yaitu analis pembiayaan, kepala cabang, dan manager marketing yang kemudian memutuskan pembiayaan tersebut disetujui atau tidak. Setelah pembiayaan dinyatakan setuju oleh komite maka dibuat Surat Penegasan Persetujuan Pembiayaan (SP3) selanjutnya pihak bank memberikan informasi kepada nasabah dengan menyebutkan syarat-syarat pembiayaan. Setelah nasabah memperoleh informasi tersebut maka dilakukan penandatanganan kontrak sebagai tanda persetujuan, setelah penandatanganan kontrak selesai kemudian dilakukan akad dihadapan notaris.

Penyerahan dana dalam pembiayaan ini melalui beberapa prosedur yaitu Bank BRI Syariah terlebih dahulu memeriksa kelengkapan persyaratan yaitu mengenai kelayakan persyaratan yang diajukan nasabah, kemudian dilihat juga kemampuan nasabah dalam mengembalikan angsuran serta kelengkapan legalitas usaha nasabah. Setelah proses pemeriksaan selesai dan dilakukan persetujuan ( $a c c)$, kemudian dilakukan akad. Setelah akad selesai dan persyaratan lengkap serta konkret kemudian dilakukan pencairan dana. Bank BRI Syariah dalam pembiayaan mudharabah produk linkage yang digunakan yaitu jenis mudharabah muqayyadah karena shahibul maal memberikan batasan mengenai dimana, bagaimana atau untuk tujuan apa dana tersebut diinvestasikan, proyek yang dijalankan terikat dengan waktu, tempat, jenis perusahaan. Dalam 
menyalurkan pembiayaan kepada anggotanya koperasi hanya menggunakan akad murabahah (jual beli) yang sudah ditentukan oleh pikah bank sebagai shahibul maal pemilihan ini sejalan dengan visi bank. Bank BRI Syariah menyalurkan pembiayaan linkage kepada koperasi dengan menggunakan mudharabah muqayyadah karena memiliki banyak manfaat baik dari beberapa pihak, yaitu : Bank BRI Syariah (shahibul maal), koperasi (mudharib) dan anggota koperasi.

\section{DAFTAR REFERENSI}

Al-ghazali, Ahmad. “Tingkat Kompotitif Pola-pola Linkage Program Pada Bank Syariah". Skripsi S1 pada Program Studi Muamalat Konsentrasi Perbankan Syariah dan Hukum Universitas Islam Syarif Hidayatullah Jakarta. 2013.

Ali, Zainuddin. 2006. Hukum Perdata Islam di Indonesia. Jakarta: Sinar Grafika.

Antonio, Muhammad Syafi'i. 2001. Islamic Banking Bank Syariah dari Teori ke Praktik. Jakarta: Gema Insani Press.

Departemen Agama RI. 2002. Mushaf Al-Qur'an Terjemah. Jakarta: Al-Huda.

Diuwaini, Dimyauddin. 2008. Pengantar Fiqh Muamalah. Yogyakarta: Pustaka Pelajar.

Fatwa DSN No. 07/ DSN-MUI/ VI/2000 tentang Mudharabah.

Ikatan Bankir Indonesia. 2015. Mengelola Bisnis Pembiayaan Bank Syariah. Jakarta : PT Gramedia Pustaka Utama.

Ismail. 2011. PERBANKAN SYARIAH. Jakarta: Kencana Prenadamedia Group.

Karim, Adiwarman A. 2011. Bank Islam Analisis Figh dan Keuangan. PT Rajagrafindo Persada.

Jubaedah . "Peran Strategis Linkage Program Bank Syariah terhadap Penguatan Lembaga Keuangan Mikro Syariah (Studi pada Bank Muamalat Indonesia)". Skripsi S1 pada Program Studi Manajemen Universitas Islam Negeri Malik Ibrahim. 2009.

Lestari, Nur Melinda. 2015. Sistem Pembiayaan Bank Syariah Berdasarkan UU No. 21 Tahun 2008. Jakarta: Grafindo Books Media.

Maesaroh, Siti. “ Efektifitas Linkage Program Bank Syariah Mandiri dalam 
Penguatan Pembiayaan Lembaga Keuangan Mikro". Skripsi S1 pada Program Studi Muamalah (Ekonomi Islam) Universitas Islam Negeri Syarif Hidayatullah Jakarta. 2011.

Mardani. 2012. Figh Ekonomi Syariah: Figh Muamalah. Jakarta: Kencana Prenadamedia Group. . 2012. Ayat-ayat dan Hadis Ekonomi Syariah. Jakarta: PT Raja Grafindo Persada.

Masniah, Siti. "Analisis Pembiayaan Mudharabah pada Koperasi Baitul Mal Wat Tanwil Maslahah Mursalah Lil Ummah (BMT-MUU) Sidogiri Pasuruan. 2007.

Muhammad. 2005. Bank Syariah Problem dan Prospek Perkembangan di Indonesia. Yogyakarta: Graha Ilmu.

Muhammad, Djibril. "BI Dorong Kerja sama Bank Syariah dan Lembaga Keuangan Mikro" dalam http://www.republika.co.id/ berita/ekonomi/ syariah-ekonomi/13/06/17//mojj14-bi-dorong-kerja-sama-bank-syariah -dan- lembaga-keuangan-mikro, artikel diakses pada tanggal 26 Oktober 2016.

Mustofa, Imam.. 2016. Fiqh Muamalah Kontenporer. Jakarta: PT Raja Grafindo Persada.

Oktafia, Fida' Nur "Analisis Pembiayaan Linkage Koperasi dengan Prinsip Mudharabah (studi pada BRI Syariah Cabang Malang)". Skripsi S1 pada Program Studi Manajemen Universitas Islam Negeri Malik Ibrahim, 2014.

- "Bank-bank Syariah Memanfaatkan executing-channeling, dalam http:// Financial.id/Newsreader/1582, artikel diakses pada tanggal 26 Oktober 2016.

Peraturan Menteri No. 03/Per/M.KUKM/III/2009

Purhantara, Wahyu. 2010. Metode Penelitian Kualitatif untuk Bisnis. Yogyakarta: Graha Ilmu

Satori, Djaman. 2013. Metode Penelitian Kualitatif. Bandung: Alfabeta.

Soemitra, Andri. 2009. Bank dan Lembaga Keuangan Syariah. Jakarta: Kencana.

Suhendi, Hendi. 2013. Figh Muamalah. Jakarta: PT Grafindo Persada.

Sujarweni, V, Wiratna. 2014. Metodologi Penelitian. Yogyakarta: pustakabarupress. 
Undang-undang No. 10 Tahun 1998 tentang Perubahan Undang-undang No. 7 Tahun 1992 tentang Perbankan.

Wawancara dengan Account Officer Anisa Alfiani Rahayu, 27 Desember 2016.

Wawancara dengan Manager Financing Support Nita Widiastuti, 14 Desember 2016.

Wawancara dengan Account Officer Faiz A.M, 20 Januari 2017.

www.brisyariah.co.id/?q=koperasi

www.brisyariah.co.id/?= sejarah

www.brisyariah.co.id/? $=$ visi-misi 